\title{
Model Development in the Context of Vocational Village Community Empowerment in Central Java
}

\author{
Dwi Yuwono Puji Sugiharto and Rafika Bayu Kusumandari
}

\begin{abstract}
For the specific purpose of this research is the creation of a model of community empowerment through the establishment of Vocational village. Referring to the objectives of the research program was designed with a "Research and Development. The results of this study: In the Village Nongkosawit, Young Interpreneur Group programs implemented are: Vocational Catering, Vocational Tailoring Skills, Vocational Aquaculture Catfish, Vocational Ranch Goat and Vocational Carpentry. In Gemawang village, Community Learning Center (CLC) Echoes of Nature Media Gemawang village, Semarang regency education Packet $\mathrm{A}, \mathrm{B}$, and $\mathrm{C}$, with 111 members. Young Interpreneur Group developed there are 14 fields in accordance with the riches Gemawang villages. Conclusion: The implementation of vocational villages have given progress in rural/urban villages run the program, each village is implementing a program to develop rural vocational potential of each locality, and the program has spawned entrepreneurs vocational villages and reduce unemployment
\end{abstract}

Index Terms-Model development, vocational village, community empowerment.

\section{INTRODUCTION}

UNESCO Instutite for Lifelong Learning (UIL) makes Indonesia as a role model eradication of illiteracy, because Indonesia successfully completed the target of eradicating illiteracy faster [1]. Indonesia in 2012 got King Sejong Literacy Award from UNESCO. Illiteracy eradication program in Indonesia addition to conventional teaching Indonesian also provide functional literacy. This functional literacy which provides independent venture capital, so that people with illiterate adults can practice the knowledge gained through his own efforts. Completion of Illiteracy in an integrated and sustainable in order to fight poverty, ignorance, under development, marginalization, and powerlessness in a society facing an increasingly competitive global as well need to be followed. It is intended that the activities and successes that have been achieved so far does not stop after the declaration free of illiteracy that has been carried out in various regions. Literacy therefore involves a continuum of learning to enable an individual to achieve his or her goals, to develop her knowledge and to participate fully in the community in which he or she lives [2]. Completion of

Manuscript received December 2, 2014; revised February 3, 2015.

Dwi Yuwono Puji Sugiharto is with Guidance and Counseling Department, Faculty of Education, Semarang State University, 50221, India (e-mail: s_dyp@ yahoo.com).

Rafika Bayu Kusumandari was with Semarang State University, 50221 INA. She is now with the Department of Educational Technology, Faculty of Education, Semarang State University, Semarang 50221, India (e-mail: mba_fika@yahoo.co.id).
Illiteracy activity is manifested in the activities of functional literacy. Functional literacy is an approach or method to develop the ability of learners to master and use the skills of writing, reading, math, thinking, watching, listening, and speaking oriented everyday life by utilizing the potential that exists in the environment around people learn [3]. There are three objectives to be achieved in the Illiteracy eradication program is proficiency in reading, writing, and arithmetic associated with the functional requirements. Functional requirements meaning that the basic needs that must be owned by a person associated with the day-to-day life to do with education. An example is the functional reading that one must have the ability to read his or her identity in identity cards, etc.

For the year 2005-2008, all the Warga Belajar (the student) has been declared free of illiteracy has gained 1 and soul 2 soul, but as many as 286503 are illiterate so get in on the basic stage. The success of the completion of illiteracy program is of course very encouraging various parties, but the need for follow-up activities that successful eradication of illiteracy so that people who had been liberated from illiteracy-free status can be empowered so that they can provide a script for a positive contribution in order to increase social welfare. To improve the welfare of the people, then formed the village formation vocational programs. Everyone in any vocation should have the ability to locate, manage, evaluate and use information for problem solving concerning their areas of vocational specialization [4]. Vocational Village is one of empowerment villages which include community development and economic empowerment. There are three areas that will be developed, namely education, health, and economy [5]. In educational activities, the activities carried out is by providing life skills training such as cooking, sewing, weaving, etc., which will be formed home industry. Life skills activities that will be provided will be tailored to the potential of each region and also with regard talents, interests and abilities of existing society. In the health sector activities, the activities carried out with the cooperation with the nearest health centers and neighborhood health center. While the field of economic activity in the form of populist economic empowerment in the form of the establishment of community-based cooperatives. The form itself in the form of savings and loans, providing cheap groceries and other community needs at a low price as well as to help people in marketing the product of the home industry they have. For home industry activities will be conducted in accordance with the characteristics and potential of each region so that available resources can be optimized. In cooperative activities will start from the stage of formation, legality komperasi to make $\mathrm{AD} / \mathrm{ART}$, entrepreneurial management training, until the establishment. 


\section{RESEARCH METHOD}

Referring to the objectives of the research program was designed with a "Research and Development", means a course of study followed by the development program for the repair or improvement [6]. To produce a prototype development of Vocational Village Model Framework for Community Empowerment in Post-Declaration of District/City Free of Illiteracy in the Education Sector, Health and Economics, taken systematic measures in the form of the process of action reflection, evaluation and innovation by applying qualitative research methods, descriptive, development, experimentation, and evaluation.

This study aims to gain in-depth overview of the Development of Vocational Education in the Context of Model Village Community Empowerment Post Declaration Regency/City Free of Illiteracy in the Education Sector, Health and Economics. The reason for the use of the use of qualitative methods because the researcher's knowledge, no results of the assessment and empirical research that specifically address the Development of Vocational Education in the Context of Model Village Community Empowerment Post Declaration Regency/City Free of Illiteracy in the Education Sector, Health and Economics. Therefore, as was common in scientific research steps taken by the researchers is to conduct assessments (exploration) of the object being studied. In this connection, a qualitative method is a method of research that offers explorative research design aims [7]. Unlike the example in the design of experimental research design qualitative research the researcher is not the starting point of a particular frame of mind, but let the research setting naturally/as is and try to understand the phenomenon that is by putting yourself in the object being studied (empathy) [8]. Qualitative research as a process of various measures involving research, theoretical and interpretative paradigm, research strategies, methods of data collection and analysis of empirical data, and the development of interpretation and presentation [9]. The location of this study took two wards/villages located in two counties/cities, Semarang City (village Nongkosawit), and Semarang District (Village Gemawang). Taking the location of this study is based on merit and the distance between researcher and research sites. The two districts are also represented on the geographical characteristics of the region and the distinctiveness of its people.

\section{RESULT}

\section{A. Model Development of Vocational Village in the Village Nongkosawit}

Model Development of Vocational Village in the Village Nongkosawit is CLC (Center for Teaching and Learning Activities). The purpose of this program is to equip students have good skills. Skill is the physical manipulative process that culminates in the achievement of ultimate goals [10]. In the presence of this CLC, Nongkosawit village had the opportunity vocational programs. The impact of literacy should be felt in vocational skills embarked upon mailing the artisans to relate literacy to their skill with a focus on enabling them to get involved in community participation in the wider community [4]. In the presence of CLC, the program gets a chance Nongkosawit vocational village. The programs are implemented :

\section{1) Vocational catering "boga mandiri"}

Skills to process food into food products that add flavor and more interesting shapes that have high sales value and interest many people. In culinary training is given on how to manufacture food, packaging techniques, and marketing techniques. Currently, businesses catering stalled due to lack of capital and marketing drag. To become a culinary entrepreneur, entrepreneur takes a tough mental. This seems less mental owned by residents that are not well developed. According to Mr. Zaenal Muttakim, culinary effort stalled because of competition with other culinary products whose price is much cheaper. Although the taste and ingredients used good quality but the price is more expensive to make society less interested in buying. To that end, the need for training on entrepreneurship is a tough mental formation. Currently, culinary products developed only wet food and side dishes that are sold in the morning.

\section{2) Tailoring vocational skills}

It is the fashion field skills with knowledge of them to make a pattern, a way of measuring, cutting the material, how to use a sewing machine properly, knowledge of the type of material and design clothes. The participants were also provided with the skills to design clothes that is a trend that is expected of consumers were not disappointed. For the quality of the stitching is also a concern because it will determine the success of the tailors in attracting consumers and enable them to compete with the already skilled seamstress and have many customers. Sewing instructor invited from the speakers are well known in the area Gunungpati so expertise is unquestioned. Participant activities are mothers and anyone who is interested in the field of sewing. They follow a course organized by the village to advanced.

\section{3) Vocational aquaculture catfish "mina tani"}

Is a program of fisheries development from seeding to enlargement. The training material provided is the introduction of other types of catfish, making the pond, feed manufacturing, irrigation models, enlargement, marketing and business management catfish. Catfish farming was once the spearhead success Nongkosawit village to village vocational achievement be the best city of Semarang in 2010 (certificate of proof in the appendix). Even from years 2009-2011 Village Nongkosawit never marketed seed catfish to Kudus and Jepara. Every day they supply fingerlings of catfish into two districts. Almost every home eventually develop this business so that none of the young men who became unemployed. However, currently surviving only about 60 people. This is due to the difficulty waters and venture capital. From this group catfish, still active today even though its business is now more to the individual, rather than group, but the association of fish farmers are always exchanging information in order to keep their businesses afloat.

\section{4) Vocational goat husbandry "bernas lestari"}

The program is a goat farm businesses ranging from the manufacture of enclosure, knowledge of the types of goats, 
feeding goats knowledge, marketing and business management. This effort developed by groups and individuals where there were about 8 people who are trying to develop seriously. Individual businesses are considered more profitable than if done in groups. However, as the group is still trying to preserved. Until now, goat breeding program continues to grow, even will be developed for dairy goat farming. Goat's milk is now a commodity that is quite profitable because it is considered to be healthier than cow's milk in which the results of research, goat milk lower the fat content and taste more delicious if properly though. Goat farm location is near the location of the development of fruits. In addition to make it easier to get food, as well as to avoid polluting the air so as not to disturb the residents.

\section{5) Vocational carpentry "gerinda raya"}

Carpentry effort was conducted by Group 1 and workshop located in the home group members. Results of carpentry is furniture, ashtrays, frames and doors. The quality of goods produced is quite nice and smooth, not inferior to the production of other places. Progress is still deemed less because of the limitations of marketing. During this time, the promotion only when the annual exhibition of the Department of Education. In addition, the availability of good timber is also an obstacle. However, carpentry businesses strive to be maintained. Mainly to give business to those who only have skills in carpentry.

In the health sector to develop Integrated Service Post for baby and the elderly. In the neighborhood health center services immunized, a child's weight, health education, supplemental foods for infants and family planning services. While the elderly are given the post of health services and counseling and the provision of supplementary food for the elderly. The existence of neighborhood health center and post the elderly can reduce infant mortality and maternal health care for the elderly and give effect to improved health for the elderly. Even Nongkosawit village had a mortality rate Maternal and child as much as $0 \%$. This is very encouraging as it shows the level of health Pregnancy and Toddlers excellent.

For the impact of the vocational village to village communities Nongkosawit very pronounced, especially in the fields of education, health and economy. From the years 2009-2011 the implementation of the program of vocational villages, many improvements and advances that have been achieved. In addition, the most important is the mindset of the people that started to change, no longer the laborer but became entrepreneurs, particularly women, although on a small scale. The following chart shows an increase from the year 2009-2013:

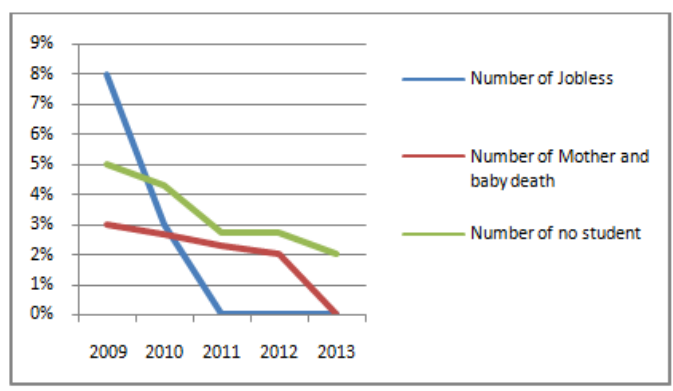

Fig. 1. Result of program in Nongkosawit village Tahun 2013.
From the above data, it appears that the number of unemployed decreased even in the year 2011-2013 unemployment rate of $0 \%$. In terms of income also increased encouraging that in 2009 the average income of the community is 500 thousand/month, in 2010 the average income of the community is 650 thousand/month and 2011 the average income of the community of 800 thousand month, in 2012 increased to 850 thousand/month, and in the year 2013 to 900 thousand/month. In addition, most of the activity was spearheaded by the youth. The youth prefer to entrepreneurship in the village, rather than as a laborer in the big cities.

\section{B. Development of Vocational Village Model Village Gemawang}

Community Learning Center (CLC) Echoes of Nature Media Gemawang village, Semarang regency education Packet A, B, and C, with 111 members. The program developed there are 14 fields in accordance with the riches Gemawang village include:

\section{1) Vocational agriculture}

The area of activity is the development of agriculture include the introduction of plant species of high economic value, plant breeding techniques, good planting techniques, maintenance and marketing of products. These efforts focused on plant breeding because the business is promising crop seed sales. Types of plants grown are sengon sea, golden teak wood and teak Netherlands, mahogany, etc. Agriculture is developed considering the geographical area village Gemawang very supportive development in agriculture.

\section{2) Vocational educational gaming equipment}

An entrepreneurship program in the field of manufacturing of tools educational games. The number of early childhood standing, requiring many tools of educational games. It makes an excellent business opportunity. To that end, the Village Gemawang trying to read and realize the opportunities in the business activities of production tools educational games. With the uptake of knowledge management-owned businesses, the community can be more productive in the village such as the creation of props for the school-level early childhood education (ECD) that can generate income.

\section{3) Vocational batik}

Is a training program to make batik from the introduction of the types of fabric, pattern recognition, batik yan good way, the way the fabric coloring, and business management. In addition, members are trained to be reliable so that batik artisans batik products in Gemawang already entered the market in Yogyakarta, and Semarang to order.

\section{4) Vocational catering}

Skills to process food into food products that add flavor and more interesting shapes that have high sales value and interest many people. This culinary skills would enhance the economy of the communities in which mothers can try to help her husband become even many primary business. In culinary training is given on how to manufacture food, packaging techniques, and marketing. Of vocational Boga, has succeeded in creating entrepreneurs, especially dry foods.

5) Vocational garment 
This garment is a vocational skill areas of fashion with the knowledge of them to make a pattern, a way of measuring, cutting the material, how to use a sewing machine properly, knowledge of the type of material and design clothes. The participants were also provided with the skills to create patterns and designs clothing trend. Vocational garment is still evolving, though not as advanced as other activities.

\section{6) Vocational mushrooms}

The air is moist and cool, very supportive of mushroom cultivation. Training materials are given in the form of a decent introduction to the type of mushroom consumption, cultivation and marketing ways. For life skills mentoring CLC with business management training in the form of village-run vocational fungus Center as an effort to improve the managerial skills of entrepreneurs. It is expected that the resulting product can be absorbed by the market.

\section{7) Vocational ranch rabbit}

Vocation have been quite a lot of food availability and demand of refined products such as rabbit satay, is quite high. The skill set of knowledge about the kinds of rabbits, the manufacture of cages, rabbit food, disease and treatment as well as a way of marketing management. Farmed rabbit is a kind of half-breed rabbits for pets usual. However, it was also developed for the type of rabbit meat consumption to sate. The results are very encouraging rabbit farming rabbit uterus because the price is quite high. This effort continues to grow and is currently increasing demand for rabbit, especially for this type of hybrid.

\section{8) Vocational catfish}

Is the catfish fishery development programs ranging from nursery to the enlargement process. The training material provided is the introduction of other types of catfish, making the pond, feed manufacturing, irrigation models, enlargement, marketing and business management catfish. The availability of water and feed abundant and easy to cultivate catfish, make this vocation attracted many residents. Cultivation has been much change the fate of villagers Gemawang. Many of those who become entrepreneurs and their economies improve.

\section{9) Vocational coffee powder}

The number of coffee plantations in the region Gemawang, making this commodity has a very good opportunity. For ground coffee vocational, training materials given is knowledge about the types of coffee, coffee processing methods, a way of packaging and marketing as well as business management. In addition, it integrates with the vocational vocational coffee plantations developed so that people do not sell their crops such as coffee beans, but coffee has been processed into a powder that has a higher economic value. Currently, in addition to package coffee powder is also being developed orginal sachet of coffee powder ready brewed with a variety of flavors. Thus, consumers have more choices in coffee consumption resulting Gemawang citizens.

\section{0) Vocational lanceng}

Lanceng is a bee house that can be used for food and also for making candles. This relates to the vocational vocational honey where the bees that had taken the honey is not discarded, but can be processed into dishes like bothok. Thus, the honeybee farmers will earn an extra income. It is of course well-liked by entrepreneurs honey. Their income not only from the sale of honey whose sales are sometimes quite long. In vocational lanceng given the knowledge of the benefits lanceng, way of processing and marketing. As it relates to the employer lanceng vocational honey is honey businessmen. During the honey business is running, it will continue to run the business lancengpun. In its development, every farmer has the creativity in lanceng processing into food products.

\section{1) Vocational honey}

The number of trees in the region make a bee Gedawang easy to do. For the vocational skills of honey to be one given for people to entrepreneurship. Content that includes types of bees trained cultivation, all kinds of honey and usefulness, way of packaging and marketing. There are a variety of honey sold from longan honey, honey kapok, etc. where each of honey have different properties.

\section{2) Vocational preparation of charcoal}

The number of hardwood trees, but can not be made into furniture gives the idea of making charcoal. Moreover, charcoal to fuel availability is often searched while increasingly difficult. The training materials include charcoal making knowledge about the types of wood, charcoal making good way, the way of packaging and marketing. Charcoal produced good quality, which is not much that destroyed so many people interested.

\section{3) Fertilizer production vocational bokhas}

The need for the development of vocational agriculture fertilizer is very high, whereas the price of fertilizers pesticides high enough so difficult to reach farmers. In addition, fertilizers pesticides have an effect that is not good for health and for the environment. The potential of plantations which pretty much makes the business of making compost can be used as a new venture. For the given vocational bokhas fertilizer. Fertilizer is the use of waste form leaves are numerous in the area Gedawang. The manufacturing process is quite easy and fertilizer produced quite good, Gedawang attract people to develop it.

\section{4) Vocational coffee plantation}

The area of land Gemawang contoured hills and have a good level of soil fertility, making commodities is well developed. For that developed vocational coffee plantations. On the vocational coffee plantation is given material on the types of coffee plants, how to provide seedlings, planting, maintenance of way, the way of fertilization, harvesting, marketing and business management. Vocational coffee plantations integrated with vocational coffee powder, although not all employers ground coffee is a coffee plantation owner. However, people are very creative Gemawang making efforts related to one another and work together in marketing. It makes Gemawang village very productive with the level of the people's economy is increasing.

Sales of the products mentioned above Gemawang village vocational than through direct sales from producers to consumers, was also taken through the center of the product Gallery Gemawang vocational Gemawang village. Gallery sells the entire product vocational Gemawang village at an affordable price. The gallery is located in an office complex 
Gemawang village hall. Jl. Raya Ambarawa-Magelang KM 12 districts of Semarang. Tel: (0298) 599555 or 081575057 271. For the impact of the vocational village to village communities Gemawang very pronounced. From the years 2009-2011 the implementation of the program of vocational villages, many improvement and progress and accomplishments already achieved. Several times Gemawang represent Semarang Regency Village to the race village in Central Java province level. In addition, the most important is the mindset of the people has changed, no longer the laborer but became entrepreneurs, particularly women, in both small and large scale. The following chart shows an increase from the year 2009-2013:

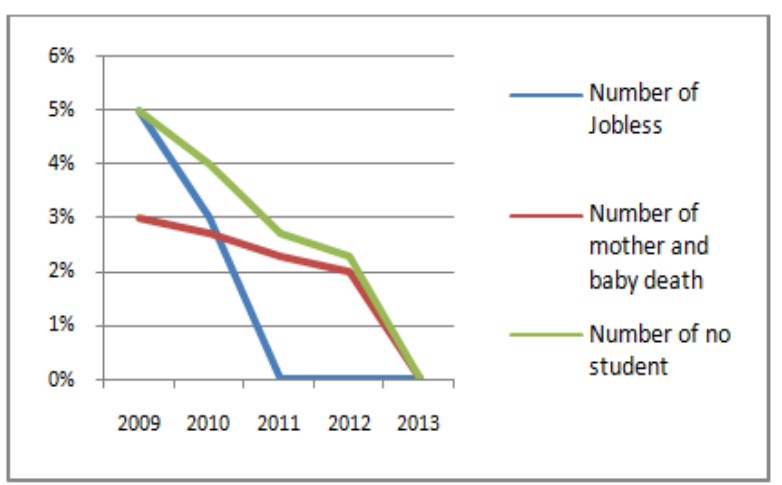

Fig. 2. Result of program in Gemawang village Tahun 2013.

From the above data, it appears that the number of unemployed decreased even in the year 2011-2013 the unemployment rate of $0 \%$. According to $\mathrm{Mr}$ Amin, Gemawang the creative community in entrepreneurship. However, lack of capital became an obstacle. In terms of income also increased encouraging that in 2009 the average income of the community is 400 thousand / month, in 2010 the average income of the community is 500 thousand / month and 2011 the average incomes of the 650 thousand / month, in 2012 increased to 9000 thousand / month, and in 2013 to 1 million / month.

\section{DISCUSSION}

One of the potential development of the village is the village vocational program in which rural areas are used as the central organizing training courses or vocational skills for work or interpreneur integrated with the management of the business units in the social, cultural and environmental dimensions to the welfare of society. Vocational Village is a form of empowerment villages include community empowerment and economic empowerment. This program aims to explore and develop the potential of the village to contribute to the alleviation of poverty and unemployment through non-formal education. Vocational Village program is done by integrating the CLC, Life Skill, public reading, early childhood education, vocational, youth program, Partnership Program with the affiliated institutions. Development of rural vocational emphasis on the provision of a number of life skills for people to poverty. Each training followed by 10-20 participants depending on their interests. Of the activity, and then further developed in some productive business groups. Thus, people who want to learn to strive to follow the existing business groups. The idea of vocational village was actually inspired by the Thai government policy through the program "One Village, One Product", which is the hometown/village is required to have a superior product. "Initially, the superior products to meet market needs only domestic. But, because taken seriously, then the top products from villages in Thailand that can penetrate the international market." Establishment of vocational village is fairly appropriate to address unemployment in Indonesia is increasingly bloated.

\section{CONCLUSION}

Implementation of vocational villages have given progress in rural / urban villages run the program.

Each village is implementing a program to develop local potential vocational villages respectively.

The program has spawned entrepreneurs vocational villages and reduce unemployment.

\section{REFERENCES}

[1] Kompasiana. [Online]. Available: http://metro.kompasiana.com/2013/10/16/unesco-beri-penghargaan-k ing-sejong-literacy-prize-601067.html.

[2] M. O. Adedokun and M. F. Oluwagbohumni, "The impact of literacy on vocational skills acquisition for better community participation," International Journal of Education \& Literacy Studies, vol. 1, no. 2, p. 12, October 2013.

[3] T. Penyusun, Pedoman Pelatihan Tutor Keaksaraan Fungsional, Departemen Pendidikan dan Kebudayaan Direktur Jendral Pendidikan Luar Sekolah Pemuda dan Olahraga, Direktorat Pendidikan Masyarakat, 1998, p. 4.

[4] M. O. Adedokun and M. F. Oluwagbohumni, "The impact of literacy on vocational skills acquisition for better community participation," International Journal of Education \& Literacy Studies, vol. 1, no. 2, p. 13, October 2013.

[5] T. Penyusun, Buku Panduan Model Penyelenggaraan Desa Vokasi, Kementrian Pendidikan Nasional, Balai Pengembangan Pendidikan Nonformal dan Informal, p. 4, 2010.

[6] S. Arikunto, "Prosedur penelitian: Suatu pendekatan praktek Jakarta: Rineka cipta," Prosedur Penelitan Suatu Pendekatan Praktek, p. 7, 2006.

[7] M. J. Moleong, Metode Penelitian Kualitatif, Bandung: Remaja Rosda Karya, 1994. ch. 2, p. 13.

[8] A. C. Alwasilah, Pokoknya Kualitatif: Dasar-dasar Merancang dan Melakukan Penelitian Kualitatif, Jakarta: Pustaka Jaya, 2003, ch. 3, p. 34.

[9] A. Salim, Teori \& Paradigma Penelitian Sosial, Yogyakarta: Tiara Wacana, p. 6, 2006.

[10] O. I. Lawal et al., "Competency capacity building needs of agricultural science teacher in utilization of school farm for skill acquisition among secondary school students," International Journal of Education \& Literacy Studies, vol. 1, no. 2, p. 2, October 2013.

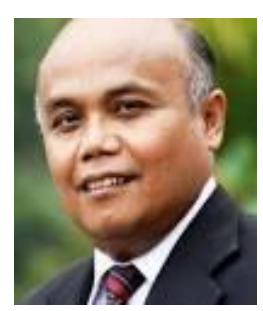

Dwi Yuwono Puji Sugiharto was born on December 1, 1961. He is a lecturer at the Department of Guidance and Counselling (BK) Faculty of Education (FIP), who is studying doctoral and master at Universitas Pendidikan Indonesia (UPI) Bandung.

He worked as the secretary of Guidance and Counseling Services Unit Student Teachers' Training College Semarang (1991-1994), and the head of Research Planning and Development Education Research Center Semarang State University (1999-2002), etc. He published a number of scientific articles both specific to the issue of counseling and education. In addition to these articles, he wrote Counseling Psychology (2007) also published. The research that has been conducted by Prof Dr. Dwi Yuwono Puji Sugiharto among others. 
Prof Dr. Dwi Yuwono Puji Sugiharto is a member of Regional Board of Guidance and Counseling Association Indonesia (2004-until now), and a member of The Executive Board of the Association of Guidance and Counselling Indonesia (ABKIN) (2005-until now), and the Vice-Chairman of the Indonesian Association of Counsellors (IKI) (2006-until now), Accreditation Board Secretary Provincial Schools/Madrasah Central Java Province, and the Chairman of Semarang State University Alumni Association (2006-until now).

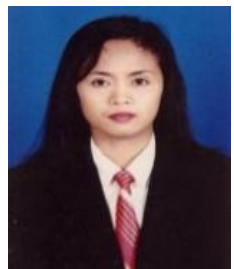

Rafika Bayu Kusumandari was born on April 15 1979. She is a lecturer at Curriculum and Educational Technology Department.

She worked as a cosultant of Education in Semarang District (2006), and the team monitoring and evaluation directorat Elementary Education Ministry of Culture and Education Indonesia (2006-2009). She is interested in research and public service. She did many researches and published many articles in some journals and books, such as "Learning management system model running in high school class Karangturi," Journal Surakarta Veteran University, etc.

Rafika Bayu Kusumandari is a member of Developers and Educational Technology Association. 